\title{
ANTIOXIDATIVE RESPONSES IN Tubifex tubifex AGAINST THALLIUM INDUCED OXIDATIVE STRESS
}

\author{
Gözde AYDOĞAN KILIÇ ${ }^{1}$, Volkan KILIÇ ${ }^{1, *}$ \\ ${ }^{1}$ Department of Biology, Faculty of Science, Anadolu University, 26470 Eskişehir, Turkey
}

\begin{abstract}
Thallium (Tl) impact on living systems has become an important issue in recent years. However very few data exist about the consequences of $\mathrm{Tl}$ exposure in freshwater aquatic systems. The aim of the present study is to investigate alterations in the levels of antioxidative biomarkers (metallothionein (MT), total glutathione (GSH), glutathione peroxidase (GPx), glutathione S-transferase (GST) and catalase (CAT)) in the aquatic oligochaete Tubifex tubifex, in response to sublethal doses of Tl. Experimental groups were exposed to thallium acetate at $0.25,0.5$ and $1 \mu \mathrm{g} \mathrm{l}^{-1}$ concentrations during 7 or 15 days. MT levels were observed to be interestingly decreased. $0.25 \mu \mathrm{g} \mathrm{l^{-1 }}$ concentration had no effect on total GSH, GPx and GST activities while 0.5 and $1 \mu \mathrm{g} \mathrm{l}^{-1}$ concentrations induced total GSH and GPx activitiy after 7 days. Longer exposure time resulted in a decrease in total GSH along with GPx and GST activities at all concentrations of Tl. Despite the significant elevation of CAT activity in all experimental groups, lipid peroxidation (LP) was observed to be induced depending on the increasing exposure concentration and time. The results suggested the possible mechanism of action in the antioxidant system of T. tubifex in response to $\mathrm{Tl}$ induced oxidative stress (OS) and provide useful information for the future evaluation of $\mathrm{Tl}$ impact on aquatic ecosystems.
\end{abstract}

Keywords: Thallium, Tubifex tubifex, Oxidative stress, Antoxidants, Lipid peroxidation

\section{Tubifex tubifex 'DE TALYUM İLE İNDÜKLENEN OKSIDDATIF STRESE KARŞI OLUŞAN ANTIOKSIDAN YANITLAR}

\begin{abstract}
ÖZET
Talyum (Tl)'un canlı sistemler üzerindeki etkisi son yıllarda önemli bir sorun haline gelmiştir. Bununla birlikte, sucul sistemlerin Tl'a maruz kalmasının sonuçları ile ilgili çok az bilgi mevcuttur. Bu çalışmanın amacı, sucul oligoket Tubifex tubifex' in antioksidan biyolojik belirteçlerinde (metallotionein (MT), toplam glutatyon (GSH), glutatyon peroksidaz (GPx), glutatyon S-transferaz (GST) ve katalaz (CAT)), TI'un subletal dozlarına yanıt olarak meydana gelen değişikliklerin araştırılmasıdır. Deney grupları $0.25,0.5$ ve $1 \mu \mathrm{g} \mathrm{l}^{-1}$ lik konsantrasyonlarda, 7 ve 15 günlük süreler boyunca talyum asetat'a maruz bırakılmıştır. MT seviyelerinde ilgi çekici bir azalma gözlenmiştir. $0.25 \mu \mathrm{g} \mathrm{l}^{-1}$ ' lik konsantrasyon toplam GSH, GPx ve GST aktiviteleri üzerinde etki göstermezken, $0.5 \mathrm{ve} 1 \mu \mathrm{g} \mathrm{l}^{-1}$ ' l1k konsantrasyonlar toplam GSH ve GPx aktivitelerini 7 günün sonunda indüklemiştir. Daha uzun maruz kalma süresi GPx ve GST aktiviteleri ile birlikte toplam GSH'un da tüm konsantrasyonlarda azalmasına neden olmuştur. CAT aktivitesinde tüm deney gruplarında gözlenen anlamlı artışa rağmen, lipid peroksidasyonunun (LP) artan konsantrasyon ve süreye bağlı olarak arttığı gözlenmiştir. Sonuçlar Tl ile indüklenen oksidatif strese karşı, T. tubifex'in antioksidan sisteminin olası hareket mekanizmasını ortaya koymakta ve Tl'un sucul ekosistemlerdeki etkileri ile ilgili gelecekte yapılacak değerlendirmeler için önemli bir bilgi kaynağı oluşturmaktadır.
\end{abstract}

Anahtar Kelimeler: Talyum, Tubifex tubifex, Oksidatif stres, Antioksidanlar, Lipid peroksidasyonu

\section{INTRODUCTION}

Thallium (TI) is a non-essential heavy metal occuring naturally at very low concentrations in the earth's crust. However it has been released to the environment in large amounts by human activities particularly in the high technology field [1,2]. Tl salts are water soluble and it possess high acute toxicity on living organisms [3]. In most aerated neutral waters, $\mathrm{Tl}(\mathrm{I})$ (thallous ion) is the predominant and the most stable form of ionic Tl. It may participate from water to sediments and can be absorbed onto some clay minerals 
and hydrous metal oxides. It has been implied that sediments may act as an active sink for TI. Thus, previous studies suggested higher levels of TI in aquatic organisms [4].

The aquatic oligochaeta Tubifex tubifex is widely distributed in freshwater sediments. Tubifex worms are exposed to contaminants mostly as a result of feeding activities on sediments [5]. They constitute an important part of the aquatic food chain and toxicity related responses in these organisms are likely to represent the effects on the whole ecosystem. Therefore, it is considered as a test organism for sediment bioassays and to assess the acute toxicity of various pollutants including metals [6-8].

Tl toxicity results in reactive oxygen species (ROS) formation and oxidative stress (OS). Cellular damage induced by ROS can be modulated by the protective effect of antioxidants [9]. Beside the endogenous antioxidants such as metallothionein (MT) and reduced glutathione (GSH) a lot of attention was given to the enzymes; glutathione peroxidase (GPx), catalase (CAT) and glutathione S-transferase (GST) in invertebrates, as potential biomarkers of metal toxicity [10]. Lipid peroxidation (LP) has also been used as a suitable marker of metal toxicity in previous studies [11].

Since much of the consequences of TI exposure is unknown in freshwater ecosystems, more detailed studies are needed in aquatic organisms, bringing special attention to the changes occuring in antioxidant systems. In order to explain mechanisms that play role in the detoxification of $\mathrm{Tl}$ in $T$. tubifex and provide information for the future evaluation of $\mathrm{Tl}$ impact on aquatic ecosystems, present study investigated the alterations in the levels of selected antioxidants (MT, GSH, GPx, GST and CAT) and LP in T. tubifex exposed to sublethal doses of $\mathrm{Tl}$ in controlled experiments.

\section{MATERIALS AND METHODS}

\subsection{Animals and Experimental Design}

The work was conducted in according to the laboratory animal care guidelines of Anadolu University. The worms were obtained from a local supplier and acclimatized for 2 weeks in a freshwater medium with pH $7.2 \pm 0.2$, dissolved oxygen (DO) $5.6 \pm 0.2 \mathrm{mg} / \mathrm{L}$, total hardness $260 \pm 7 \mathrm{mg} / \mathrm{L}$ as $\mathrm{CaCO}_{3}$ and temprature $20.2 \pm 1{ }^{\circ} \mathrm{C}$. All experiments were conducted in a light-dark cycle of $12 \mathrm{~h}$. The water was continuosly aerated, renewed weekly and the animals were fed with TetraMin Flakes (Tetra Werke, Germany) once a week. They were starved $24 \mathrm{~h}$ before and during the experiments. Healthy animals were transferred from the stock tank into glass aquariums containing 11 of distilled water with the density of 10 animals per $100 \mathrm{ml}$. TI was added from a stock solution as thallium (I) acetate (Sigma St Louis USA). There was a control and six experimental groups $(n=3)$. Sublethal doses of TI were administrated during 7 and 15 days at $0.25,0.5$ and $1 \mu \mathrm{g}^{-1}$ concentrations to the experimental groups. Control worms were placed in another aquarium with uncontaminated water. Temprature and lightening conditions were as mentioned. All assays were run at least triplicate.

\subsection{Determination of Thallium Content}

Worms were oven-dried $\left(48 \mathrm{~h}\right.$ at $\left.70{ }^{\circ} \mathrm{C}\right)$ to constant weight. Samples were digested in $5 \mathrm{ml}$ of concentrated $\mathrm{HNO}_{3}$ at $60{ }^{\circ} \mathrm{C}$. The digestate was diluted 1:1 (v:v) with double distilled water. The detection limit for $\mathrm{Tl}$ was $2 \mu \mathrm{g} \mathrm{l}^{-1}$ in Perkin Elmer Optical Emission Spectrometer Optima $4300 \mathrm{DV}$ [12].

\subsection{Metallothionein (MT) Analysis}

The metallothionein was assesssed according to the method of Viarengo et al. (1997) [13]. Samples (1:3) were homogenized in Tris-HCl buffer ( $\mathrm{pH}$ 8.6) containing $0.5 \mathrm{M}$ sucrose, $0.0006 \mathrm{mM}$ leupeptine, $0.5 \mathrm{mM}$ PMSF (phenylmethylsulphonylfluoride) and $0.001 \%$ mercaptoethanol. The homogenate was 
then centrifuged at $30.000 \mathrm{~g}$ for $20 \mathrm{~min}$ to obtain the supernatant containing MTs. Ethanol/chloroform precipitation was carried out to obtain a partially purified metallothionein fraction. Quantification of MT concentration was performed by spectrophotometric titration of the sulphydryl residues using the Ellman's reagent. The amount of MT was calculated by using reduced glutathione as a standard [13, $14]$.

\subsection{Total Glutathione (GSH), Glutathione Peroxidase (Gpx), Glutathione S-Transferase (Gst) And Catalase (Cat) Measurements}

$1 \mathrm{~g}$ of frozen worms from each replicate were pooled together, snap-frozen in liquid nitrogen and grounded, then homogenized in $0.1 \mathrm{M}$ phosphate buffer ( $\mathrm{pH}$ 7.6) containing $1 \mathrm{mM}$ EDTA and $0.25 \mathrm{M}$ sucrose. The homogenate was centrifuged at $10.000 \mathrm{~g}$ for $10 \mathrm{~min}$. The supernatant was stored at $-80{ }^{\circ} \mathrm{C}$ until analysis. Protein contents were determined by the method of Bradford (1976) [15].

Total glutathione (total GSH) levels were determined by using a Bioxytech GSH-400 colorimetric kit (Oxis International Inc., Portland, OR, USA) based on the formation of a chromophoric thione by a three-step reaction. The absorbance measured at $420 \mathrm{~nm}$ was directly proportional to the GSH concentration. Results are expressed as micromoles of GSH per gram of tissue. Glutathione peroxidase (GPx; EC 1.11.1.9) activity was determined by a modification of the coupled assay procedure of Lawrence and Burk (1976) [16]. $\operatorname{GPx}\left(\mathrm{H}_{2} \mathrm{O}_{2}\right)$ activity was coupled to NADPH utilization and the production of $\mathrm{NADP}^{+}$was measured spectrophotometrically at $340 \mathrm{~nm}$. The amount of enzyme oxidizing 1 umol of reduced glutathione per min was defined as one unit of enzyme activity. Results are expressed as units of activity per milligram of protein. Glutathione $S$-transferase (GST; EC 2.5.1.18) activity was measured according to Habig et al. (1974) [17] through the conjugation of GSH with 1chloro-2,4-dinitrobenzene (CDNB). The rate of increase in absorbance was measured at $340 \mathrm{~nm}$. Results are expressed as units of activity per milligram of protein. Catalase (CAT; EC 1.11.1.6) activity was assayed according to Beers and Sizer (1952) [18] by following the decomposition of hydrogen peroxide at $240 \mathrm{~nm}$. Results are expressed as units of activity per milligram of protein.

\subsection{Assay of Lipid Peroxidation}

The LP status was monitored through the formation of thiobarbituric acid reactive substances (TBARS) [19]. Samples were homogenized in $1.15 \% \mathrm{KCl}$ solution $10 \%(\mathrm{w} / \mathrm{v})$. An aliquot of the homogenate was added to a reaction mixture containing $8.1 \%$ sodium dodecyl-sulfate, $20 \%$ acetic acid and $0.8 \%$ thiobarbituric acid. Samples were then heated at $95{ }^{\circ} \mathrm{C}$ for $60 \mathrm{~min}$. TBARS were extracted with n-butanol and pyridine $(15: 1$, $\mathrm{v} / \mathrm{v})$. Absorbance was measured at $532 \mathrm{~nm}$. Results were expressed as nmol TBARS per milligram of protein.

\subsection{Statistical Analysis}

All data were analyzed by use of the SPSS 11.5 software package. A one-way analysis of variance was used to determine whether a significant difference existed between experimental groups and controls, followed by multiple comparison post hoc test. Data are expressed as mean \pm standard deviation (SD), and differences were considered statistically significant if $\mathrm{P}<0.05$.

\section{RESULTS}

\subsection{Tissue Thallium Concentrations}

$\mathrm{Tl}$ content of the worm samples in control and experimental groups is shown in Table 1. Control worms had no TI cocentrations above the detection limits. The amount of $\mathrm{Tl}$ in tissues of worms was obseved to be increased depending on the exposure concentration and time. 
Table.1. Tissue thallium concentrations in T. tubifex exposed to $0.25,0.5$ and $1 \mu \mathrm{g}^{-1}$ concentrations of thallium acetate after 7 and 15 days. All values are mean \pm SD.

\begin{tabular}{|c|c|c|}
\hline \multirow{2}{*}{ Exposure Concentration } & \multicolumn{2}{|c|}{ Tissue Tl Content $(\mu \mathrm{g} / \mathrm{g}$ wet weight $)$} \\
\cline { 2 - 3 } & 7 days & 14 days \\
\hline $0.25 \mu \mathrm{g} / 1$ & $0.017 \pm 0.001$ & $0.037 \pm 0.004$ \\
\hline $0.5 \mu \mathrm{g} / 1$ & $0.025 \pm 0.001$ & $0.061 \pm 0.008$ \\
\hline $1.0 \mu \mathrm{g} / 1$ & $0.053 \pm 0.002$ & $0.108 \pm 0.011$ \\
\hline
\end{tabular}

\subsection{Metallothionein Levels}

MT levels decreased significantly depending on the exposure concentration. The rate of decrease was about $25.7 \%, 41.7 \%$, and $45.8 \%$ for the three increasing doses of Tl after 7 days. 15 days of exposure resulted in a more dramatical decrease at the levels of MT which was about $59.7 \%, 68.4 \%$ and $75.3 \%$ lower than the control at the doses of $0.25,0.5$ and $1 \mu \mathrm{g}^{-1}$ respectively (Figure 1 ).

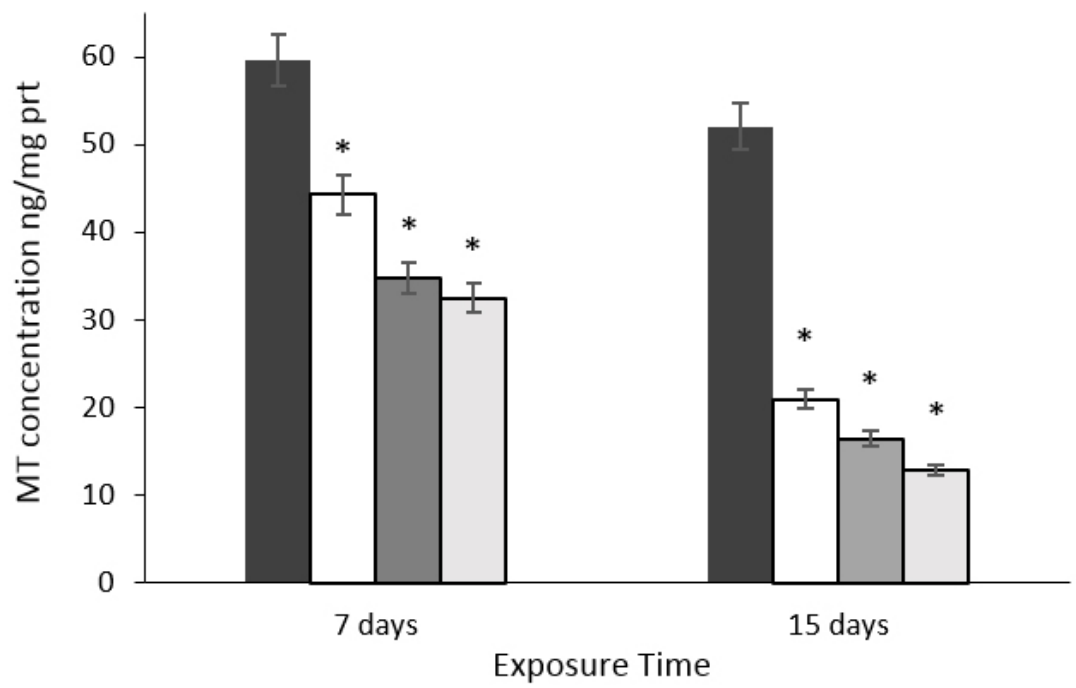

Figure 1. Metallothionein levels in T. tubifex exposed to $0.25,0.5$ and $1 \mu \mathrm{g}^{-1}$ concentrations of thallium acetate after 7 and 15 days. All values are mean \pm SD (One-way ANOVA). * represents statistically significant differences from control $(\mathrm{P}<0.05)$.

\subsection{Total Glutathione (Gsh) Levels, Glutathione Peroxidase (Gpx), Glutathione S-Transferase (Gst) And Catalase (Cat) Activities}

Figure $2 \mathrm{a}-\mathrm{b}$ is representing total GSH levels and GPx activity while Figure $3 \mathrm{a}-\mathrm{b}$ is representing GST and CAT activities in Tl exposed worms. Tl at the dose of $0.25 \mu \mathrm{g} \mathrm{l}^{-1}$ had no effect on total GSH, GPx and GST activities of animals after 7 days. 0.5 and $1 \mu \mathrm{g}^{-1}$ concentrations increased total GSH levels (64.7\% and $110.6 \%$ respectively) and induced GPx activitiy (25.4\% and $22.43 \%$ respectively). Longer exposure time resulted in a decrease at the levels of total GSH, GPx and GST at all concentrations of Tl. The rate of decrease was between $16.4 \%$ and $39.12 \%$ for total GSH; $20.2 \%$, and $52.8 \%$ for GPx; and $13.0 \%$ and $40.5 \%$ for GST after 15 days (Figure 2a-b, Figure 3a). Tl toxicity resulted in an induction of CAT activity in T. tubifex for three experimental doses at all the time. The rate of increase was between $114.6 \%$ and $172.3 \%$ after 7 days and between $95.3 \%$ and $108.5 \%$ after 15 days. Longer exposure to Tl (15 days) induced a decrease of the CAT activity which remained clearly higher than control levels (Figure 3b). 

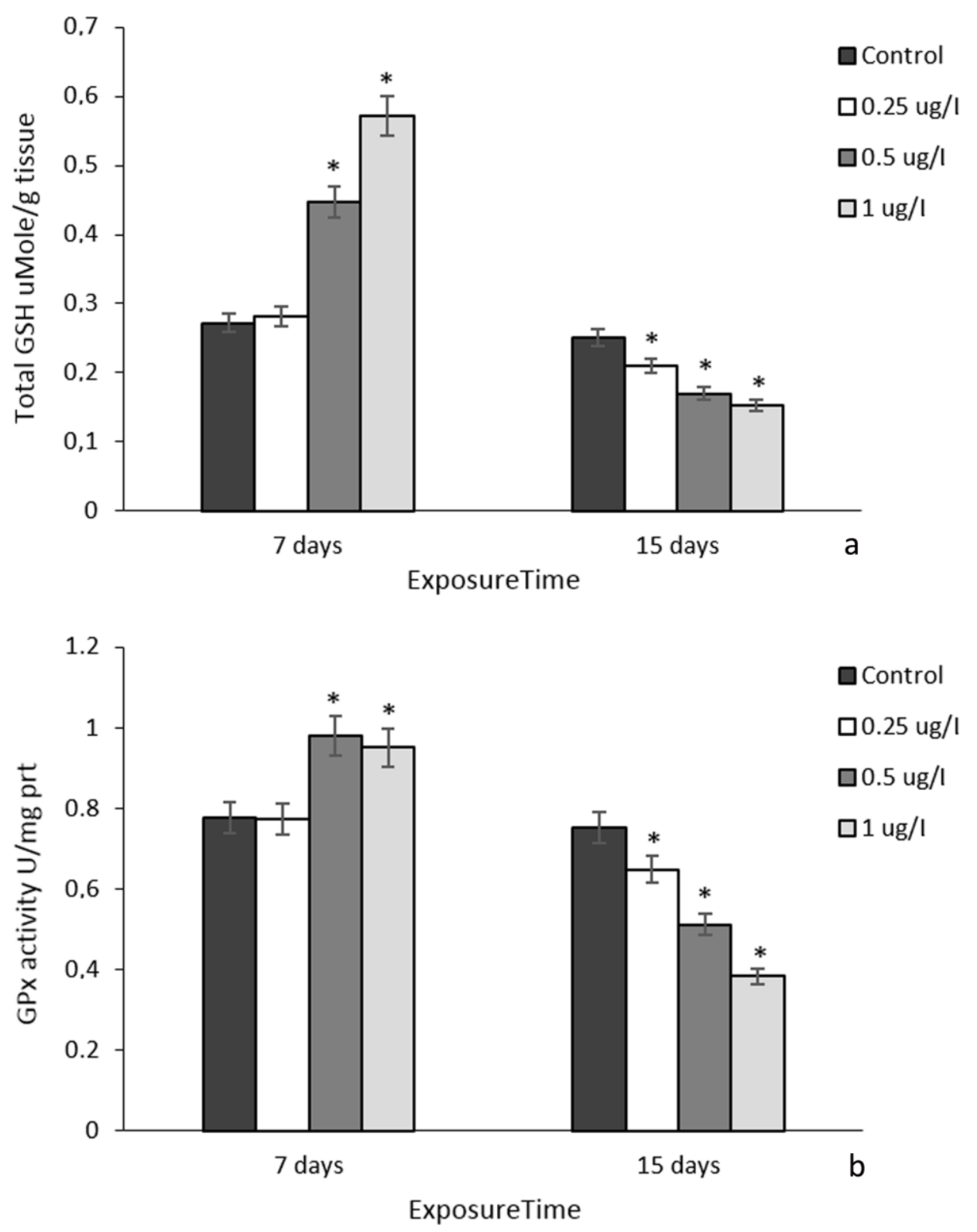

Figure 2. a- Total glutathione levels in T. tubifex exposed to $0.25,0.5$ and $1 \mu \mathrm{g} \mathrm{l}^{-1}$ concentrations of thallium acetate after 7 and 15 days. b- Glutathione peroxidase activity in T. tubifex exposed to $0.25,0.5$ and $1 \mu \mathrm{g}^{-1}$ concentrations of thallium acetate after 7 and 15 days. All values are mean $\pm \mathrm{SD}$ (Oneway ANOVA). * represents statistically significant differences from control $(\mathrm{P}<0.05)$. 

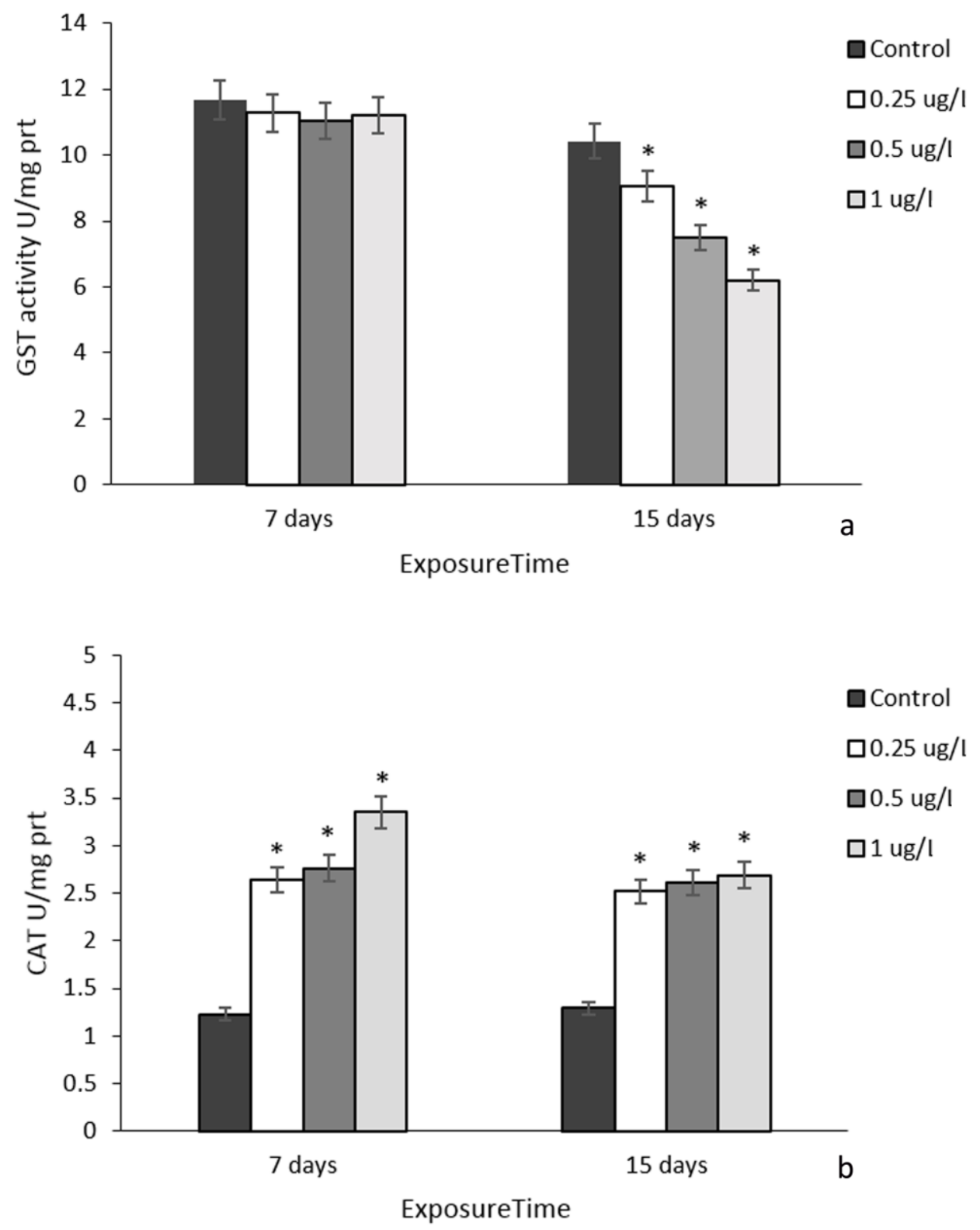

Figure 3. a- Glutathione S-transferase activity in T. tubifex exposed to $0.25,0.5$ and $1 \mu \mathrm{g}^{-1}$ concentrations of thallium acetate after 7 and 15 days. b- Catalase activity in T. tubifex exposed to $0.25,0.5$ and 1 $\mu \mathrm{g}^{-1}$ concentrations of thallium acetate after 7 and 15 days. All values are mean $\pm \mathrm{SD}$ (One-way ANOVA). ${ }^{*}$ represents statistically significant differences from control $(\mathrm{P}<0.05)$. 


\subsection{Liqid Peroxidation}

LP was observed to be increased in $0.25 \mu \mathrm{g} \mathrm{l^{-1 }}(11.8 \%)$ after 7 days but the difference was not significant when compared to control. For other groups, the significant increase in LP was dependent on the concentration of $\mathrm{Tl}$ and exposure time. The rate of increase was $33.7 \%$ and $82.2 \%$ at the doses of 0.5 and $0.25 \mu \mathrm{g} \mathrm{l}^{-1}$ after 7 days and between $51.3 \%$ and $117.6 \%$ after 15 days (Figure 4).

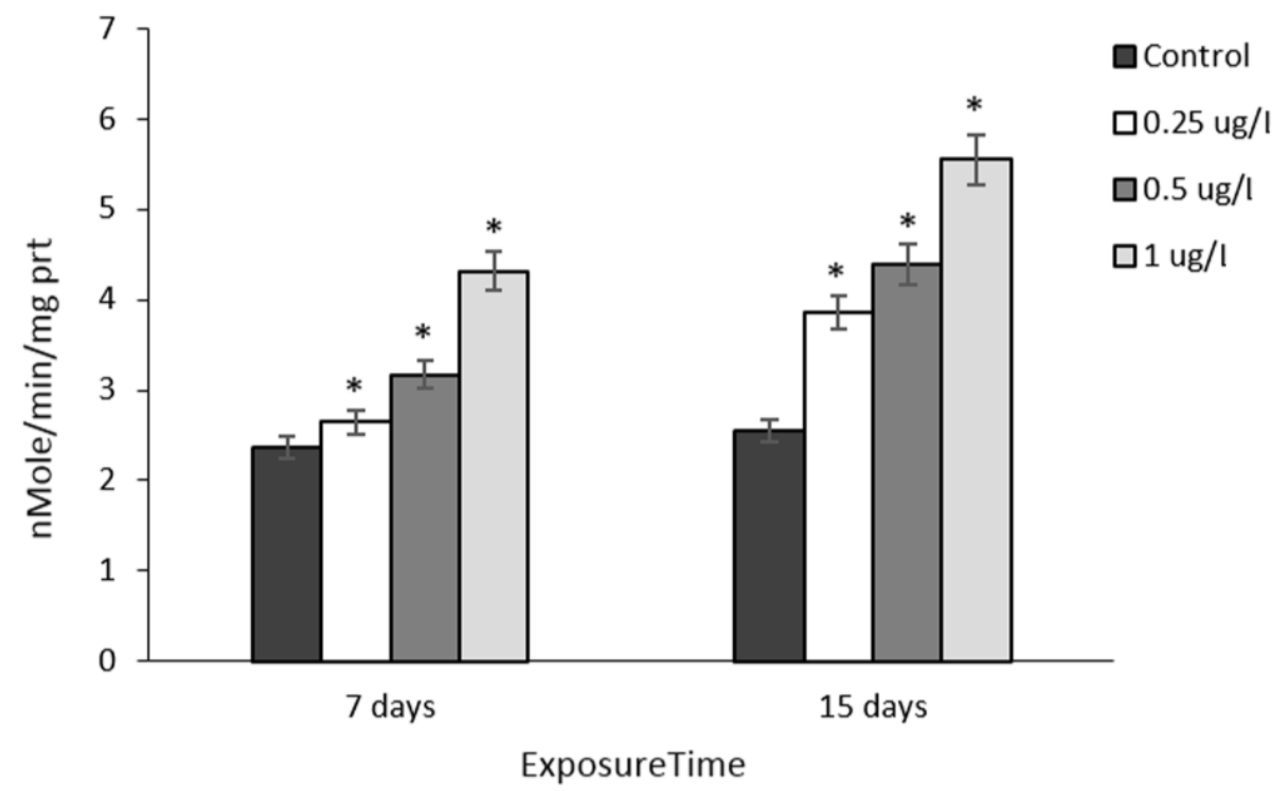

Figure 4. Lipid peroxidation in T. tubifex exposed to $0.25,0.5$ and $1 \mu \mathrm{g}^{-1}$ concentrations of thallium acetate after 7 and 15 days. All values are mean \pm SD (One-way ANOVA). ${ }^{*}$ represents statistically significant differences from control $(\mathrm{P}<0.05)$.

\section{DISCUSSION}

Little is known about the toxic mechanisms induced by $\mathrm{Tl}$ in aquatic organisms. Previous studies on Tubifex worms were mainly focused on the distribution of $\mathrm{Tl}$ in these animals or discussed the acute toxic effects on their survival [20,21]. Here, we investigated changes in the levels of selected biomarkers (MT, total GSH, GPx, GST and CAT) in T tubifex, in order to clarify the precise role of antioxidant mechanisms in these worms in relation to $\mathrm{Tl}$ toxicity.

Exposure to $\mathrm{Tl}$ did not induce MT synthesis in experimental group animals. Besides, increased TI concentration resulted in a decrease in MT levels depending on the increasing dose and exposure time (Figure 1). In contrast to our results, MT had been observed to be induced in a large variety of species contaminated by metals. In the earthworm Lampito mauritii administration of lead $(\mathrm{Pb})$ and zinc $(\mathrm{Zn})$ resulted in a significant increase in tissue MT level [22]. Copper $(\mathrm{Cu})$ toxicity resulted in an induction in the synthesis of T. tubifex MT [23]. Cadmium (Cd) and Zn exposure elevated MT levels in Daphnia magna [24]. On the other hand, exposure to $\mathrm{Cu}$ did not effect the synthesis of MT in the polychaete Perinereis nuntia [25]. Electron probe X-ray microanalysis revealed that TI does not induce generation of sulfhydryl-rich molecules including MT [26]. However results of a previous study of our group suggested an interaction between MT and Tl. Exogenous administration of MT prevented TI- sulfhydryl rich protein interactions and oxidative stress by increasing antioxidant capacity [12].

GSH and MT are the two antioxidant molecules which share some important similarities. Indeed, cysteines constitute one third of the both molecules aminoacids thus making them reactive to chemicals 
or metals [27]. "Glutathione system" has shown to be effective as a defense mechanism against Cd toxicity [28]. However limited evidence exists for other metals. Our results showed that Tl exposure at the dose of $0.25 \mu \mathrm{g} \mathrm{l}^{-1}$ for 7 days had no effect on total GSH, GPx and GST activities of animals. GSH synthesis and GPx activity were induced as a result of increasing exposure concentration, however, GST activity was stable after 7 days (Figure 2a-b, Figure $3 a$ ). $\mathrm{H}_{2} \mathrm{O}_{2}$ and other peroxides are detoxified by the enzyme GPx. GSH is the substrate of this reaction. Moreover, it can be conjugated to electrophilic xenobiotics by activity of GST or it can act as a direct scavenger of pro-oxidants such as transition metals [10]. In the present study GSH appears to be constituting a first line defense in $T$. tubifex against OS induced by $\mathrm{Tl}$ through the action of GPx. Tl exposure after 15 days of an experimental period resulted in a decrease in total GSH, GPx and GST in T. tubifex at all of the tested concentrations (Figure 2a-b, Figure 3a). Supporting these results, an vitro study investigating the effect of $\mathrm{Tl}(\mathrm{OH})_{3}$ on the normal functioning of the glutathione depending antioxidant defense system indicated that $\mathrm{Tl}(\mathrm{OH})_{3}(1-25 \mu \mathrm{M})$ significantly decreased the content of reduced GSH caused by GSH oxidation and inhibited GPx activity. TI could react with GSH and reduce the effective GSH concentration [2]. When GSH is depleted by any metal, GSH synthesizing systems start making more GSH from cysteine. However, GSH is usually not effectively supplied in chronic metal exposure conditions[29]. The dose dependent increase in total GSH in T tubifex after 7 days of sublethal $\mathrm{Tl}$ exposure following a decrease in a longer period of time can be explained as a result of these mentioned conditions. On the other hand, GSH and MT share the same cysteine pool in the cell for their biosynthesis [30]. Therefore, the decrease in MT depending on the increasing exposure time and concentration may be attributed to the limited cellular cysteine availability inside the cell.

Antioxidant defense enzymes may protect this imbalance resulted from GSH depletion [29]. Tl toxicity resulted in an induction of CAT activity in T. tubifex for three experimental doses at all the time. 15 days exposure to $\mathrm{Tl}$ decreased CAT activity however it was still higher than the control levels (Figure 3b). Similarly, $\mathrm{Cu}$ exposure at 50,100, and $200 \mu \mathrm{g} \mathrm{l^{-1 }}$ concentrations for 7 and 15 days resulted in an increase in CAT activity in T tubifex. Cu exposure also showed a decrease in GST after 7 days of exposure [22]. Activities of antioxidant enzymes in Tigriopus japonicus, exposed to different metals arsenic (As), cadmium $(\mathrm{Cd})$, copper $(\mathrm{Cu})$, silver $(\mathrm{Ag})$, and zinc $(\mathrm{Zn})$ were highly elevated showing that antioxidant enzymes act as an important cellular defense mechanisms against metal toxicity in this organism [31].

GSH depletion impairs cellular defense against the toxic action of compounds such as hydroperoxides or other oxidants [27]. Membrane lipid peroxidation is a critical initiating event of cell damage. Loss of permeability/functions of the membranes results in a serious homeostasis imbalance. In a study evaluating the effects of UV-B radiation in T. tubifex as a model organism, total GSH contents were observed to be decreased significantly while TBARS increased and GST activity was inhibited [32]. Similarly, TI toxicity resulted in a significant elevation in LP for all of the experimental groups with the exception of $0.25 \mu \mathrm{g}^{-1} 7$ days exposed animals (Figure 4). Progressive elevation in LP depending on the increasing exposure concentration and time assumed to be mediated by the suppression of antioxidant system as a result of $\mathrm{Tl}$ toxicity.

\section{CONCLUSIONS}

According to the findings of the present study, MT levels interestingly decreased in T. tubifex and GSH estimated to be the key component of the defense system against Tl induced OS. The role of GPx, GST and MT are thougt to be modulated depending the cellular levels of total GSH. OS caused by Tl exposure at the dose of $0.25 \mu \mathrm{g}^{-1}$ was tolerable during 7 days of experimental period. CAT activity increased to prevent the imbalance resulted from GSH depletion. However with the increasing concentration and time, antioxidant protection was observed to be suppressed resulting in an increase in peroxidation of tissue lipids. These results manifested the possible mechanisms of action in the antioxidant system of $T$. 
tubifex in response to $\mathrm{Tl}$ toxicity and expected to be a contribution for the future evaluation of $\mathrm{Tl}$ impact on aquatic ecosystems.

\section{REFERENCES}

[1] Hanzel CE, Villaverde MS, Verstraeten SV. Glutathione metabolism is impared in vitro by thallium (III) hydroxide. Toxicology. 2005; 207: 501-510.

[2] Villaverde MS, Hanzel CE, Verstraeten SV. In vitro interactions of thallium with components of the glutathione-dependent antioxidant defence system. Free Radical Res.2004; 38(9): 977-984.

[3] Kemper FR, Bertram HP. Thallium. In: Metals and their compounds in the environment Occurrence, analysis, and biological relevance, VCH, New York. 1991

[4] Peter AL, Viraraghavan T. Thallium: a riview of public health and environmental concerns. Environ. Int. 2005; 31: 493-501.

[5] Smutna M, Hilscherova K, Paskova V, Marsalek B. Biochemical parameters in Tubifex tubifex as an integral part of complex sediment toxicity assessment. J.Soils Sediments. 2008; 8: 154-164.

[6] Lucan-Bouche ML, Habets F, Biagianthi-Risbourg S, Vernet G. Toxic effects and bioaccumulation of cadmium in the aquatic oligochaete Tubifex tubifex. Ecotoxicol. Environ. Saf. 2000; 46: 246-251.

[7] Rathore RS, Khangarot BS. Effects of temprature on the sensitivity of sludge worm Tubifex tubifex Müller to selected heavy metals. Ecotoxicol. Environ. Saf. 2002; 53: 27-36.

[8] Mosleh YY, Paris-Palacios S, Couderchet M, Biagianti-Risbourg S, Vernet G. Effects of herbicide isoproturon on metallothioneins, growth and antioxidative defenses in the aquatic worm Tubifex tubifex (Oligochaeta, Tubificidae). Ecotoxicology. 2005; 14(5): 559-571.

[9] Galvan-Arzate GS, Chaverri JP, Campos ONM, Maldonado PD, Roman BV, Rios C, Santamaria A. Delayed effects of thallium in the rat brain: regional changes in lipid peroxidation and behavioral markers but moderate alterations in antioxidants, after a single administration. Food Chem. Toxicol. 2005; 43: 1037-1045.

[10] Saint-Denis M, Fabrot F, Narbonne JF, Ribera D. Glutathione, glutathione related enzymes, and catalase activities in the earthworm Eisenia fetida andrei. Arch. Environ. Contam. Toxicol. 1998; 35: 602-614.

[11] Galvan-Arzate SG, Martinez A, Medina E, Santamaria A, Rios C. Subchronic administration of sublethal doses of thallium to rats: effects on distribution and lipid peroxidation in brain regions. Toxicol. Lett. 2000; 116: 37-43.

[12] Aydoğan Kılıç G, Kutlu M. Effects of exogenous metallothionein against thallium-induced oxidative stres in rat liver. Food Chem. Toxicol. 2010; 48:3: 980-987.

[13] Viarengo A, Ponzano E, Dondero F, Fabbri R. A simple spectrophotometric method for metallothionein evaluation in marine organisms: an application to Mediterranean and Antarctic molluscs. Mar. Environ. Res. 1997; 44 (1): 69-84. 
[14] Lukkari T, Taavitsainen M, Soimasuo M, Oikari A, Haimi J. Biomarker responses of the earthworm Aporrectodea tuberculata to copper and zinc exposure: differences between populations with and without earlier metal exposure. Environ. Pollut. 2004; 129 (3): 377-386.

[15] Bradford MMA. Rapid and sensitive method for the quantitation of microgram quantities of protein utilizing the principle of protein dye-binding. Anal. Biochem. 1976; 72: 248-254.

[16] Lawrence RA, Burk RF. Glutathione peroxidase activity in selenium deficient rat liver. Biochem. Biophys. Res. Commun. 1976; 71 (4): 952-958.

[17] Habig WH, Pabst MJ, Jakoby WB. Glutathione S-transferase: The first enzymatic step in mercapturic acid formation. J. Biol. Chem. 1974; 249: 7130-7139.

[18] Beers RF, Sizer IW. Spectrophotometric method for measuring the breakdown of hydrogen peroxide by catalase. J. Biol. Chem. 1952; 195: 133-140.

[19] Ohkawa H, Ohishi N, Yagi K. Assay for lipid peroxides in animal tissues by thiobarbituric acid reaction. Anal. Biochem. 1979; 95: 351-358.

[20] Dumas J, Hare L. The internal distribution of nickel and thallium in two freshwater invertebrates and its relevance to trophic transfer. Environ. Sci. Technol. 2008; 42: 5144-5149.

[21] Kılıç V, Altunsoy F, Aydoğan Kılıç G. Effect of thallium on the survival and morphology of Tubifex tubifex (Oligochaeta,Tubificidae). Fresenius Environ. Bull. 2011; 20:_2442-2445.

[22] Maity S, Roy S, Bhattacharya S, Chaudhury S. Metallothionein responses in the earthworm Lampito mauritii (Kinberg) following lead and zinc exposure: A promising tool for monitoring metal contamination. Eur. J. Soil Biol. 2011; 47: 69-71.

[23] Mosleh YY, Paris-Palacios S, Biagianti-Risbourg S. Metallothioneins induction and antioxidative response in aquatic worms Tubifex tubifex (Oligochaeta, Tubificidae) exposed to copper. Chemosphere. 2006; 64: 121-128.

[24] Fan WH, Tang G, Zhao CM, Duan Y, Zhang R. Metal accumulation and biomarker responses in Daphnia magna following cadmium and zinc exposure. Environ. Toxicol. Chem. 2009; 28: 305-310.

[25] Won EJ, Raisuddin S, Shin KH. Evaluation of induction of metallothioneinlike proteins (MTLPs) in the polychaetes for biomonitoring of heavy metal pollution in marine sediment. Mar. Pollut. Bull. 2008; 57: 544-551.

[26] Zierold K. Heavy metal toxicity studied by electron probe X-ray microanalysis of cultured rat hepatocytes. Toxicol. in Vitro. 2000; 14: 557-563.

[27] Haidara K, Moffatt P, Denizaeu F. Metallothionein induction attenuates the effects of glutathione depletors in rat hepatocytes. Toxicol. Sci. 1999; 49: 297-305.

[28] Mosleh YY, Paris-Palacios S, Ahmed MT, Mahmoud FM, Osman MA, Biagianti-Risbourg S. Effects of chitosan on oxidative stress and metallothioneins in aquatic worm Tubifex tubifex (Oligochaeta,Tubificidae). Chemosphere. 2007; 67(1):167-75.

[29] Ercal N, Gurer-Orhan H, Aykin-Burns N. Toxic metals and oxidative stress part I: mechanisms involved in metal induced oxidative damage. Curr Top Med Chem. 2001; 1: 529-539. 
Aydoğan Kılıç and Kılıç / Anadolu Univ. J. of Sci. and Technology C-Life Sci. and Biotech. 6 (2) - 2017

[30] Hidalgo J, Garvey JS, Armario A. On the metallothionein, glutathione and cysteine relationship in rat liver. J. Pharmac. exp. Ther. 1990; 255: 554-564.

[31] Kim BM, Rhee JS, Jeong CB, Seo JS, Park GS, Lee YM, Lee JS. Heavy metals induce oxidative stress and trigger oxidative stress-mediated heat shock protein (hsp) modulation in the intertidal copepod Tigriopus japonicus. Comp. Biochem. Physiol. C Toxicol. Pharmacol. 2014; 166: 65-74.

[32] Misra RB, Babu S, Ray RS, Hans RK. Tubifex: A Sensitive Model for UV-B-Induced Phototoxicity. Ecotoxicol. Environ. Saf. 2002; 52: 288-295. 